\title{
THE VOCAL REPERTOIRE OF THE YELLOW-THROATED HONEYEATER, LICHENOSTOMUS FLAVICOLLIS
}

\author{
by Penelope J. Bruce
}

(with one table and two text-figures)

BRUCE, P.I., 1988 (31:x): The vocal repertoire of the yellow-throated honeyeater, Lichenostomus flavicollis. Pap). Proc. R. Soc. Tasm. 122 (2): 135-138. https://doi.org/10.26749/rstpp.122.2.135

ISSN 0080-4703. Zoology Department, University of Queensland, St Lucia, QId, Australia 4067; formerly Department of Zoology, University of Tasmania.

Vocalisations of the yellow-throated honeyeater were recorded at Mount Nelson, and throughout northern and eastern Tasmania. Territorial songs, calls associated with territorial disputes, and calls given by parents and young during the breeding cycle are described.

Key Wørds: vøcalisations, søngs, call, yellow-thrøated høneyeater, Tasmania.

\section{INTRODUCTION}

The yellow-throated honeyeater Lichenostomus flavicollis is endemic to Tasmania. It belongs to a group of monogamous, noncooperative honeyeaters that defend all-purpose territories all year round. The female is apparently territorial only during the breeding season and, in some cases, returns to the same territory in successive years (Bruce \& Wilson, unpubl. data). Throughout the year males defend a territory of around 0.5 ha. A single female and fledglings are resident on the territory during the breeding season (Bruce 1984).

Although Littler (1903) described the yellowthroated honeyeater as possessing vocalisations practically limited to "a loud whistle-like note often repeated", Anon. (1976) and Pizzey (1980) describe a variety of songs and calls. This paper details the different vocalisations of the yellow-throated honeyeater and includes notes on the contexts in which they occur.

\section{METHODS}

Vocalisations were recorded in the field between February and October 1984. Most of the work was conducted in the University Reserve at Mount Nelson, although recordings were made throughout northern and eastern Tasmania. Eight birds were colour banded at Mount Nelson, including four males and one female that were residents on five different territories. Recordings were made with a Sony TC-D5 M cassette recorder coupled with a pre-amplifier, and a Nakamichi condensor microphone with a shotgun capsule attachment. Careful notes were taken on the behaviour of focal birds.

Throughout this paper the following definitions will apply. A syllable is the shortest continuous segment of a vocalisation. Interval refers to the distance in time between two syllables and duration is the length of the syllables. Harsh vocalisations usually consist of multiples of pure tones. The lowest of these is called the fundamental frequency and the higher frequencies are called the harmonics of the syllable.

\section{RESULTS AND DISCUSSION}

\section{Territorial Songs}

Three types of song were used in the territorial advertisement and/or mate attraction. These were based on a series of short, repeated syllables, the loudest being audible over a distance of half a kilonetre in ideal conditions. The usual position for the performance of the songs was in a conspicuous place at the top of eucalypts, dead branches being particularly favoured. If a male heard a song from a nearby bird, it would work its way up to the top of a tree in its own territory, singing at regular intervals, and finally remain at the top singing. The songs were characteristically sung in response to a nearby male's song. Table 1 describes the frequency and temporal features of these songs. 


\section{TABLE 1}

\section{Frequency and Temporal Characteristics of Territorial Songs at Mount Nelson}

Note that the breeding song consists of two-syllable song phrases. The duration and frequency columns contain two values referring to these syllables in order.

\begin{tabular}{|c|c|c|c|c|}
\hline & & & Song & \\
\hline & & Non-breeding & Trill & Breeding \\
\hline No. syllables - & mean & 4 & 15 & 7 \\
\hline & range & $1-10$ & $5->100$ & \\
\hline Interval (ms) - & phrase & - & - & 419 \\
\hline & syllable & 590 & 447 & 101 \\
\hline Duration (ms) - & syllable & 36.6 & 36 & 60,150 \\
\hline Frequency $(\mathrm{kHz})-$ & maximum & 1.9 & 1.8 & $2.9,2.1$ \\
\hline & minimum & 1.3 & 1.3 & $0.92,0.99$ \\
\hline & range & $0.8-2.8$ & $0.8-2.0$ & $0.6-3.3$ \\
\hline
\end{tabular}

No. songs sampled

52

4

75

\section{Non-breeding Song (Fig. 1A)}

This song has been described as the "tonk" call (Anon. 1976). It is used throughout the year by males. Soft non-breeding songs were occasionally heard from females. Robinson (1949) states that in birds that pair for life and hold permanent territories, both sexes tend to be equally vocal. This was not the case with the yellow-throated honeyeater, however it is uncertain whether these birds pair for life.

\section{Trill Song (Fig. 1B)}

The trill song was present all year. It was occasionally preceded by an aggressive call and, from about February to March, by one or two "tonk" syllables. This song usually followed a territorial boundary dispute.

\section{Breeding Song (Fig, 1C)}

This song was introduced by the male at the beginning of the breeding season. The stimulus for the song was probably the arrival of females in the territory. The dates that the song was first heard in different study areas were: Mount Nelson 18 June, Nunamara - 30 June, Reedy Marsh between 23 July and 20 August, and Underwood between 1 July and 20 August. The song varied between local populations from a two-syllable "dewitt" to three- and four-syllable songs (Bruce 1987).

\section{Aggressive Call}

This harsh call was used by the male and female before and after boundary disputes, in response to nearby song, in interspecific aggression and to the author around the nest site. In one case it continued for 12 minutes. The fundamental frequency of this call was around $1 \mathrm{kHz}$ with harmonics at 2, 4 and $8 \mathrm{kHz}$. An amplitude emphasis was present at $4 \mathrm{kHz}$.

\section{Interaction Call}

The interaction call was always associated with physical confrontation in territorial boundary disputes. It was a high pitched, harsh call that consisted of rapidly repeated syllables. Two typical postures adopted during such interactions are 

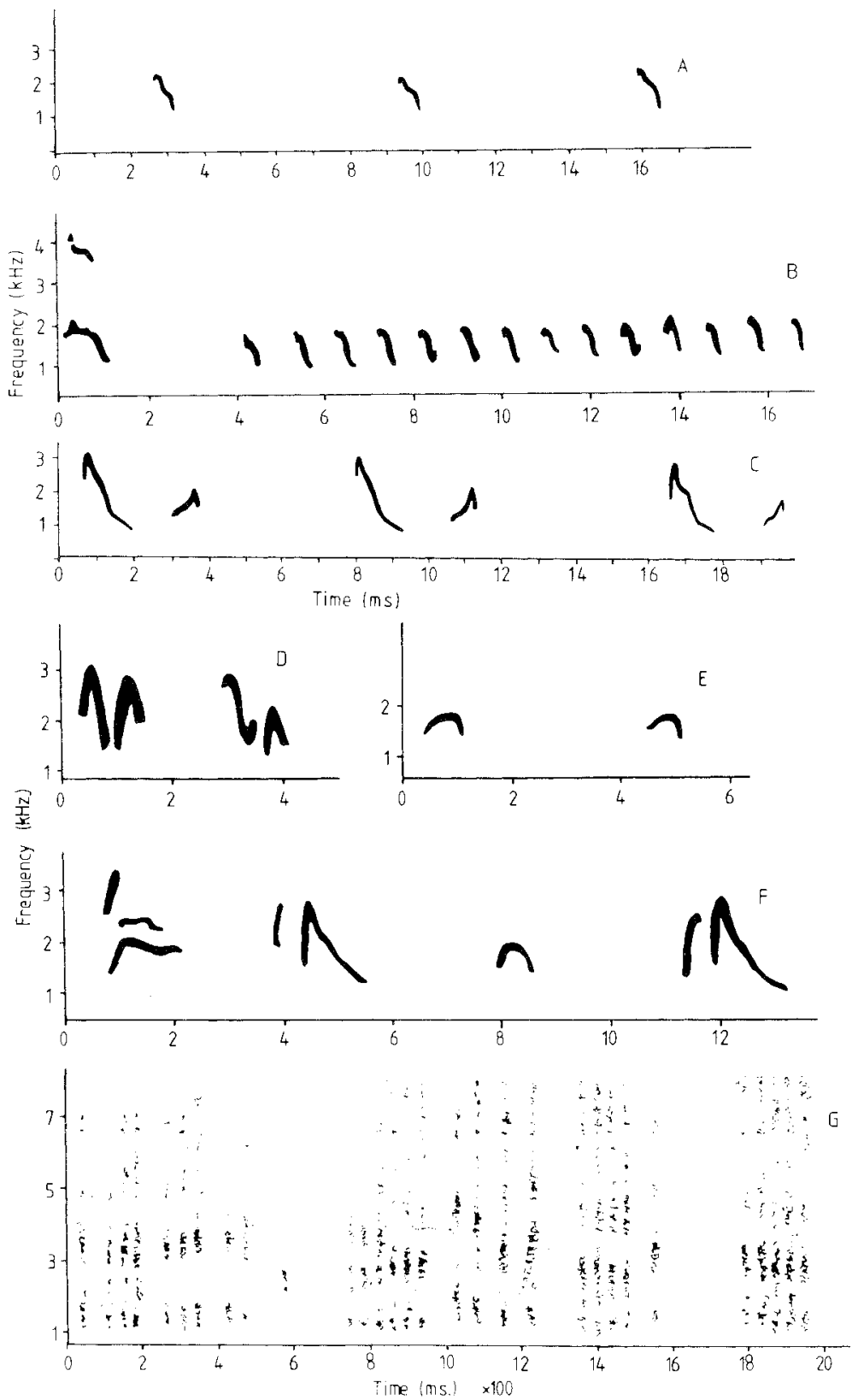

FIG. I - Vocalisations of the yellow-throated honeyeater at Mount Nelson. (A) non-breeding song; (B) trill song with a "tonk" preceding it; $(C)$ breeding song; $(D)$ "cheep" call of the nestlings and fledglings; $(E)$ "cheep" call of the female; $(F)$ call of the adult female on arrival at the nest with food; and $(G)$ call of the adult female when she attempted to collect hair from the author's head. 


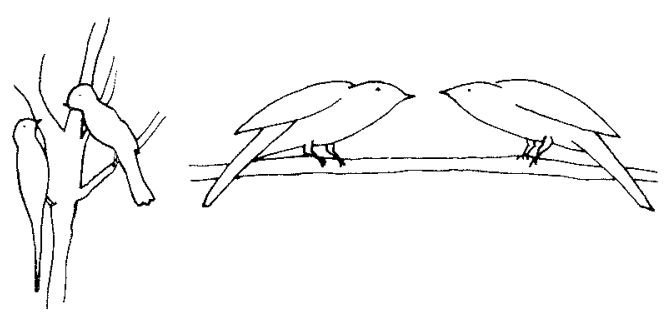

FIG. 2 - Postures associated with the interaction call.

show $\mathrm{n}$ in figure 2 . The fundamental frequency was at $2 \mathrm{kHz}$, with harmonics at 4,8 and $16 \mathrm{kHz}$. An amplitude emphasis occurred at $4 \mathrm{kHz}$.

\section{Nest Distraction Display}

A harsh squeal-like call given by the male during the nest distraction display. This display consisted of flapping the wings in the undergrowth about $5 \mathrm{~m}$ from the nest, or running along the ground while alternatively flapping the wings.

\section{Calls used by the Nestling and Fledglings}

Figure 1D shows the "cheep" call given by nestlings and fledglings whilst begging for food. A second call was used by the nestlings from the time the female landed near the nest to when she left. This was a harsh call, containing harmonics, but was shorter in duration than aggressive and interaction calls.

\section{Calls used by the Female}

Figure 1E shows the "cheep" call used by the female when chased from a territory and when the male showed driving behaviour towards her.
Figure $\mathrm{IF}$ is a call used by the female when she attempted to collect hair from the aurhor's head. Note that this call included a soft version of the Mount Wellington breeding song (Bruce 1987) alternated with the "cheep" call. Figure $1 \mathrm{G}$ is a call used when the female approached the nest to feed the young. The male also used this call when feeding the fledglings.

\section{ACKNOWLEDGEMENTS}

This work was undertaken as part of the B.Sc. Honours course at the University of Tasmania. I am grateful to the supervisor of the project, Dr I. S. Wilson, for his encouragement and advice.

\section{REFERENCES}

ANON., 1976: COMPLETE BOOK OF AUSTRALIAN BIRDS. Readers' Digest, Sydney.

BRUCE, P.J., 1984: The song and behaviour of the yellow-throated honeyeater Lichenostomus flavicollis, Vieillot 1813. Unpubl. B.Sc. Hons thesis, Univ. Tasm.

BRUCE, P.J., 1987: Spatial and individual variation in the song of the yellow-throated honeyeater, Lichenostomus flavicollis. Emu 88: 65-69.

LITTLER, F.M., 1903: Notes on some birds peculiar to Tasmania. Emu 3: 81-89.

PIZZEY, G., 1980: A FIELD GUIDE TO THE BIRDS OF AUSTRALIA. Collins, Sydney.

ROBINSON, A., 1949: The biological significance of bird song in Australia. Emu 48: 291-315.

(accepted 14 December 1987) 